\title{
Empoderamento e trajetórias de vida: uma relação visualizada
}

\author{
Gênero, classe e etnia: trajetórias \\ de vida de mulheres migrantes.
}

LISBOA, Teresa Kleba.

Florianópolis: Ed. da UFSC; Chapecó: Argos, 2003. 192 p.

Ao discutir as histórias de migração do oeste e centro-oeste para a capital de Santa Catarina, Teresa Lisboa articula as categorias de gênero, classe e etnia, resgatando as peculiaridades de vida de mulheres caboclas pobres. A história de opressão vivenciada pelos povos de origem indígena, expulsos ou exterminados das/nas terras do interior do estado, é pintada através da descrição de condições precárias de vida, nas quais as perspectivas de trabalho restringiam-se ao baixo assalariamento rural e à condição de posseiros provisórios de pequenas extensões de terra. A autora também dá ênfase ao misticismo corrente no cotidiano dessas pessoas, destacando a importância dos rituais originados na convivência com os monges atuantes nas lutas do Contestado.

A esse primeiro momento de caracterização sócio-histórica da região de origem que é percorrida através de narrações coletivas e individualizadas, personificadas nas falas dos próprios atores pesquisados, segue-se uma singularização do trabalho. Essa singularização é possibilitada pelo maior delineamento das pessoas pesquisadas, apontando a vinculação dos entrevistados a duas gerações diferentes (60) 92 anos e 29/44 anos) e a indicação do número de participantes, 13 pessoas, sendo dez mulheres e três homens. Tais mulheres e homens vindos do oeste e centro-oeste de Santa Catarina, principalmente das cidades de Caçador e Chapecó, direcionaram-se para as comunidades do Morro do Horácio e Santa Teresinha II, localizadas na periferia de Florianópolis. De trabalhadores rurais, em sua maioria, assumiram postos principalmente como faxineiras, no caso das mulheres, e na construção civil, no caso dos homens. O acesso a uma renda exígua e o pouco acesso aos bancos escolares, que resulta em uma escolaridade que atinge no máximo o ensino fundamental, também são representativos nesse grupo de sujeitos.

A visualização do percurso traçado por esses sujeitos é possibilitada, primeiramente, pela indicação das motivações para o abandono do meio agrícola. A autora situa os sujeitos em um momento histórico (últimas décadas do século XX) caracterizado pela intensa crise no campo, repercutindo em um êxodo rural representativo em decorrência, entre outras causas, da mecanização agrícola e dos parcos investimentos nessa área produtiva. A partir dessa ênfase na situação mais global, são apresentadas as histórias de migração com suas respectivas peculiaridades. Entre os motivos da passagem do interior para a capital do estado, são apontados pelos sujeitos pesquisados a presença em Florianópolis de familiares na Penitenciária Estadual de Santa Catarina e a morte ou separação de parentes como a mãe ou o marido, - que provoca a busca de outros familiares na capital e a procura por melhores condições de trabalho e atenção à saúde.

O esboço do momento seguinte, a chegada a uma nova cidade, é dado através da apresentação das articulações dessas pessoas migrantes com redes sociais de apoio. A importância dos familiares (abrangendo laços de parentesco e "compadrio"), já destacada na apresentação das motivações para a migração, é resgatada nesse momento, somando-se à relevância da vizinhança e das Organizações NãoGovernamentais, estas representadas predominantemente por grupos ligados à Igreja Católica e à Universidade Federal de Santa Catarina. As relações desenroladas com essas diferentes redes sociais propiciam mediações para 
as permanências e as transformações culturais enfrentadas no processo de mudança territorial. Nesses espaços, são estabelecidos conflitos envolvendo questões de gênero, classe e etnia e é possibilitado o processo de empoderamento a partir de características articuladas a estas mesmas categorias, mulher, pobre e cabocla. A autora reconstrói, então, as histórias de empoderamento de quatro mulheres, cujas vidas estão articuladas com as problemáticas anteriormente desenvolvidas, e de uma agente externa, cujo trabalho está diretamente ligado ao empoderamento das outras informantes. São sublinhados diversos componentes do processo de empoderamento, como as reivindicações por casa própria, a conquista de maior divisão de responsabilidades com o marido no espaço doméstico, a participação em lutas comunitárias e sociais, através da inserção em associações de moradores e movimentos sociais, e o compartilhar da história de vida através de projetos acadêmicos.
A singularidade das mulheres participantes é apresentada ao longo de toda a construção do trabalho, articulando as relações de gênero, classe e etnia. O destaque da autora recai, porém, sobre a importância de certos constituintes da cultura cabocla, como a valorização da figura materna, a solidariedade, a coragem, a resistência e a significação positiva da etnia cabocla, $\circ$ que possibilita maior representatividade política dessas mulheres em suas comunidades. É possível, dessa forma, acompanhar diferentes trajetórias, com suas particularidades, sem deixar de perceber os elos que as ligam e que possibilitam uma compreensão dessas histórias de maneira emancipadora.

Aline Drews Universidade Federal de Santa Catarina 